\title{
Philosophies of the mind and body: Descartes, Ricouer and the metaparadigm of nursing
}

\author{
Rudolf Cymorr Kirby P. Martinez¹, Lourlyn P. Mansaguiton², Myrna A. Mercado³, and Iril I. Panes ${ }^{4}$
}

Date Received: $\quad$ 11th of September, 2017

Date Accepted: $\quad$ 5th of December , 2017

\begin{abstract}
This paper presents an analysis of Descartes and Ricouer's philosophies which explores the nature and connection of the mind and body, in terms of their tenets, similarities, differences as well as their implication to the understanding of the metaparadigm in nursing. The first part of the paper gives a brief background on the philosophers and their philosophies focusing on Descartes' Dualism then comparing it to Ricouer's concept of "Selfhood". Meanwhile, the second part of this paper deals with how these two philosophies affect our understanding of the metaparadigm in nursing (Fawcett, 1984) specifically, the concept of person, health, environment, and nursing.
\end{abstract}

Keywords: Descartes, metaparadigm, mind-body, philosophy, Ricouer

\section{The PHILOSOPHIES}

Descartes' Mind-Body Dualism. Rene Descartes, born in the French province of Touraine, is a French philosopher, mathematician and scientist known to be the father of modern philosophy. Early in his life, he was influenced by the work of Beeckman, who engaged in a project that explained phenomena mechanistically in terms of matter in motion. Later on, Descartes developed a unified system of knowledge explaining the existence of a fixed law by which natural phenomenon abide (Papineau, 2009). However, during the time when Galileo was condemned in Rome for maintaining that the earth was in motion, Descartes completely changed his plans and instead shifted his focus on discovering the ideas of the mind, matter and God.

Descartes' shift in focal interest allowed him to develop his philosophy on mind-body dualism best exemplified by his philosophical statement "Cogito ergo sum" (I think, therefore I exist) (Murray \& Chamberlain, 1999). Further, his philosophy tries to establish absolute certainty on the understanding of things. Descartes' Discourse on the Method, published in 1637, proposes to set a fundamental principle to consider any false belief even with the slightest doubt which would deprive anyone in seeking for the truth (Skirry, 2005). To do that, he employed a method known as methodological skepticism, a stance that reject doubtful ideas. This implies three things: (a) that in order to seek for the truth, it is necessary to doubt as far as possible; (b) presume that something is not true until proven that it is true; and (c) systematic but tentative doubt is a prelude to genuine knowledge. Doubting of sensible things is one of the general approaches to the truth. This takes us into the element of Descartes' thinking on rationalism. Descartes believes that only through reason can one arrive at the truth and the perception of the senses is doubtful. His doubt on use of the senses to understand the truth can be understood through the "argument of the wax". Descartes argue that the senses are the means of knowing a piece of wax, its properties, characteristics and physical attributes. However, when fire melted the

1. ORCID Number: 0000-0002-5323-5108, R.C.K.P. Martinez is with the College of Nursing, San Beda College, Mendiola Manila, 1005, Philippines; the Florentino Cayco Memorial School Graduate School of Nursing, Arellano University, Legarda Manila, 1008, Philippines (e-mail: rmartinez@sanbeda.edu.ph).

2. ORCID Number: 0000-0001-5394-5911, L. P. Mansaguiton, is with the College of Nursing, Mountain View College, Valencia City Bukidnon, 8709, Philippines (e-mail: lourlynpagonzaga@gmail.com).

3. ORCID Number: 0000-0003-4288-2358, M. A. Mercado is with the College of Nursing, Mountain View College, Valencia City Bukidnon, 8709, Philippines (email: myrnamercado67@yahoo.com).

4. ORCID Number: 0000-0001-6687-3734, I.I. Panes is with the College of Nursing, Sultan Kudarat State University, Tacurong City, 9800, Philippines (e-mail: myrnamercado67@yahoo.com)

University of the Visayas Journal of Research 
wax, its attributing properties changes. Though our sense does not see the wax in its original form, we still know that it is wax. Our understanding of the piece of wax then proves that the thing we believe and understood before through our senses is not reliable. Our senses are extensions of our body that would only see measurable things just like that of wax but we did not understand what wax is because we did not scrutinize it using our reasons (McBean \& Wijck, 2013).

The primacy of reason to understand the truth was further exemplified when Garrett (2014) points out that for Descartes, each one must plead to reasons as the only source of knowledge. Moreover, Descartes also post it that the use of reason can develop the natural science and lay the ground that philosophy is a thinking system that embodies all knowledge. He was the first person in modern times who built a philosophy that stands head on in self-confidence generated by rational knowledge which concluded that the basic philosophy comes from reason, not feeling, not faith, not verse, nor other sources (Bennett, 1994).

Additionally, Descartes philosophy places great emphasis on the process of reduction to understand a concept. McBean and Wijck (2013) pointed out that Descartes reduces the complexity of a phenomenon via the process of reductionism, by breaking it down to more rudimentary pieces of constructs. Applying this process, he proposes that a person is healthy when the body is in good working order but he does not fully accept the idea that humans are just machinery so he postulated another entity: the mind. For Descartes, the mind was everything, an immaterial thinking substance, un-extended and not subject to mechanical laws while the body is a material, non-thinking substance, extended and subject to mechanical laws and measurements (Hutchin, 1952). As McBean and Wijck (2013) would summarize it "By postulating the two mutually exclusive entities, of body and mind Cartesian dualism was introduced" (p.4). Thus, by taking Descartes' view, the foregoing presentation expresses the existence of the mind and the body as different entities, which exist in two different planes. The body is tangential while the mind is essential.

Ricouer's Philosophy of Selfhood. Jean Paul Gustave Ricoeur (1913-2005) was a continental philosopher, a creative writer, whose works expound on the meaning of life. His writing runs through the major theme of philosophical anthropology, a philosophical discipline that enquires into the essence of human nature and the human condition (New World Encyclopedia, 2015).

Moreover, philosophical anthropology seeks to understand the nature of human beings through its consideration of these two questions as a methodological approach: "Who am I?" and "What is a human being?" For Ricouer, understanding the nature of selfhood - the state of having an individual identity, is a prelude to understanding the nature of self. For Ricouer, to be a true master of the self, humans should fully understand themselves, their selfhood. Opposed to Descartes' idea of mind-body dualism, Ricoeur rejected the idea of a metaphysical self and focus on selfhood instead of the concept of an entity (Atkins, 2016). Ricouer's concept of selfhood is a dialectic of activity and passivity since human are beings characterized by his/her "double nature" or "double allegiance" - the material world of cause and effect and the immaterial world of the will (Atkins, 2016). Though Ricouer rejects the idea of an entity, his notion of selfhood is parallel to Descartes's notion of dualistic world of the material body and the immaterial mind. Moreover, Ricouers' concept of selfhood, like that of Descartes, entails that human beings need to possess both the mind and body in order to exist and to interact with the outside world. Both argues that the body is essential since it serves as a vessel for the mind to exist. What sets Ricouer's idea apart from the mechanistic duality of Descartes is the belief that the mind and body are always in constant interaction with each other since there is always a tension between the involuntary constraint of humans, being a subject of the world and the voluntariness necessary to the idea of the self as agents of actions. Despite this polarity, Ricouer asserts in the existence of a complementarity in the two dimensions of human existence (Pellauer \& Daunenhauer, 2016), but not totally harmonious.

Additionally, in answering the question "What is a human being?", Ricouer asserts that they are "capable" human beings (Pellauer \& Daunenhauer, 2016), that is by nature they have the capacity to become vulnerable, fallible and culpable because he is not a perfect being, and these imperfections make them completely human (Garcia, 2011) since perfection can only be attributed to God. For Ricouer, what makes human beings unique among God's creation is that they are intellectual beings and have the capacity to reason. This is again analogous to Descartes appreciation of the mind as a distinctive possession of human being, the agent by which human beings "know" of things. If Descartes believes in the fundamental notion of doubting as a means of knowing, Ricouer proposes the use of textuality as a basis for analysis of meaning (Siringan, 2011). For Ricouer, all knowledge, as well as man's knowledge of his own existence, not merely composed 
of accurate facts but a combination of various areas of discussion about all aspects of human life, is not immediately transparent and needs to be understood through the interpretation of the expression of the self through one's actions, symbols, myths, metaphors and texts. It must be noted however, that for Ricouer, all knowledge is of value in an effort to understand oneself, including the knowledge perceived by the senses. The inclusion of knowledge known thru the senses is a notion that Descartes vehemently frowned upon since he asserts that only the knowledge appreciated by the mind is of value. Perception then is embraced by Ricouer and rejected by Descartes.

The foregoing discussion then asserts that in Ricouer's understanding, the constant interaction and struggle of the mind and body to resolve this inherent tension gives human beings their distinctive individual identities as opposed to Descartes' belief of the primacy of the mind as the sole determinant of an individual's personhood.

Essentially, Ricouer's knowing can be seen as inclusive, pragmatic and polysemic while Descartes' is exclusive, skeptical and singular.

\section{Mind-Body PHILOSOPHIES AND METAPARADIGMS IN NURSING}

Metaparadigm serves as a way to understand disciplinary concepts, i.e. domain, of a profession as it provides a perspective of a discipline (Masters, 2009). Eckberg and Hill (1979) said that it "acts as an encapsulating unit or framework, within which the more restricted structures develop" (p.927). The metaparadigm for nursing describes concepts that define the discipline of nursing, namely - human being, environment, health, and nursing. Specifically, these four concepts are about: "The person receiving the nursing, the environment within which the person exists, the health-illness continuum within which the person falls at the time of the interaction with the nurse, and finally, the nursing actions themselves" (Flaskerud \& Holloran, as cited by Fawcett, 1994, p.5).

These four (4) essential elements of nursing paradigm as proposed by Fawcett (1981) and its interconnectedness to the principles of Cartesian Dualism and Ricouer's Selfhood is described in the succeeding paragraph.

Person. The metaparadigm of persons in nursing focuses on human being as the recipient of care. It encompasses the nature of persons and how it relates to the practice of the discipline of nursing.

Both the tenets of Cartesian Dualism and Ricouer's Selfhood argues that human being is composed of two standalone but interacting components; the mind and the body. The immaterial mind controls and gives "substance" to the material body to act and that the senses are the extensions of the body, the same way as reason is the workings of the mind. This is parallel to the position of Rummelsburg (2015) when he asserts that the person is a physical and material being which interacts to the world through his senses. Dualism posits that the "two components" of a person is distinguishable from each other. Thus, one can focus on understanding each part as it is. Since the mind and the body are separate from each other, they can exist, in theory, even without the presence of the other, such as death. This paved the way to "demythologized" the body and opened society's view on the ethics of conducting autopsies (McBean \& Wijck, 2013) which further improved our knowledge of the human body and its workings. Moreover, this appreciation of the body provides a clearer understanding on the objective, factual and knowable aspects of the body and its disorders. Maville and Huerta (2012) further assert that this separation of mind and body from the teachings of Descartes has allowed investigation and treatment to focus on the illness of the body having only a few diseases coming from the mind. This resulted to the development of mechanistic models of the body that started the use of biomedical and technological interventions to treat diseases (White, 2006). Additionally, it could also be argued that dualism also steered further the understanding of the workings of the mind since they are co-equal separate entities. Furthermore, Hooft (2006) posits that dualism has contributed to the understanding of the individuality of a person "allowing health care workers to define their task as being centered on the body alone" (p.24). Had it not been for dualism, focusing on the client's body alone will not be possible.

On the other hand, more than just being an intellectual mind in a mortal body, Ricouer's sense of selfhood elevated the discourse from the question "what is a human being" to "who am I" and in the process brought back humanity to the understanding of a person. For Ricouer, human beings are "capable" human beings. They have the fundamental capabilities (strengths) as well as vulnerabilities (weaknesses). These strengths and weaknesses is what makes human beings human since they are capable of mastering themselves through self- knowledge. But then, selfknowledge, according to Ricouer, is not immediately transparent or known to man. That is why Ricoeur always poses the question "What is the meaning of being human?" in all his scope of study. This is for man 
to continue seek self-understanding and his essence of being in the world. It can be assumed therefore that Ricouer's focus shifted from the Descartes' epistemological question of human being to a more ontological perspective.

It is also among the tenets of Ricouer's selfhood that

he emphasized that a human being is a social creature that the self is contingent to the collective social memory. We are not just alone, we are contingent and constructed by what is going on before which is part of our collective social memory and experiences in the past.

Lastly, Ricoeur considers that human subjectivity is primarily through language and symbols. He also underscores the significance of learning and understanding the transition in the experience of people's lives through narratives. Ricoeur considers "Self as a construct". In his book the "Rule of the metaphor" he said that, human beings construct themselves in a narrative that they wish to create our life's story (Siringan, 2011). Human beings create narratives of self in the frame of time in the past, present and future. They create stories of themselves that reflects who they are in the past and present what they would like to be in the future (Flaming, 2005). This is parallel to Benner's definition of a human person as a living person embodied in the world who is a "selfinterpreting being, that is, the person does not come into the world pre-defined but gets defined in the course of living a life " (Benner \& Wrubel, 1989, as cited by Masters, 2009 p. 55). The human person therefore is a continuously evolving conscious and rational being creating, destroying and recreating himself as he/she integrate new experiences into his/her individual personhood and not merely a mind trapped in a mortal body, as was proposed by dualism.

Human beings - or persons are the recipients of care. Both Descartes and Ricouers' precept on human beings, although with some opposing ideas is that both advocates care. Descartes' Dualism makes possible for health care workers to attend to physical problems, and Ricouers' Selfhood enables health practitioners to care for persons beyond the physical aspect but holistically. The focus of the discipline of nursing, health will be discussed in the succeeding section.

Health. The metaparadigm of health provides an overview on how the nature and appreciation of the concept of health. Further, it explores how meanings attached to health affect the nature of nursing as a discipline.
The Cartesian dualism provides a grounding of the mechanistic model of the body. For Descartes, a person is healthy as long as the body is in good working order (McBean \& Wijck, 2013). But for the body to exist and function, the mind needs to be efficient as well. This was reiterated by Descartes when he said that how a person feels, thinks and interprets their disease affects their treatment such as in cases of pain and its management (McBean \& Wijck, 2013). This is parallel to Beerman, Snyder and Frandsen (2016) definition of health as the degree of wellness and well-being that a person experiences. The senses, as the extension of the body, perceived the external and internal cues that the body is in "good working order" and it is the mind that ultimately interprets and appreciates these cues. This is congruent to the appreciation of health by Dorothea Orem as the "soundness or wholeness of developed human structures and of bodily and mental functioning" (Orem, 1995, p. 101)

On the other hand, it can be deduced from the tenets of Ricouer's selfhood that health is the attainment of the full capacity of a human being. Since he proposes that humans are capable creatures, being created with the capacity to reason out, judge and comprehend, exercising their capacity in search for humanity enables them to attain their highest potential. It goes beyond the mere absence of disease or infirmity but full health can only be appreciated if human being have attained their full potential, that is, they are well aware of who they are as a person. But Ricoeur also stressed that humans as their nature requires, have intrinsic vulnerabilities and fallibilities which might lead to their shortcomings. Inability to adjust to life stressors is one of a human's vulnerability. Being able to adjust and learn from this vulnerability can then lead humans to attain a healthy character, and eventually, a healthy life. As Beerman, Snyder, and Frandsen (2016) claimed, a person is healthy when he is able to adapt to the environment and with the interaction in the environment. This is parallel to Imogene King's health definition - a dynamic human experience characterized by the optimal use of one's resources and capabilities in order to continuously adjust to stressors in the environment, both external and internal; which eventually results in the attainment of the individual's maximum potential (Masters, 2009).

For Ricouer then, being healthy is but a conscious choice. Flaming (2005) summed this up when he said "In a philosophical way, Ricoeur promotes the idea that a healthy self-identity happens when someone constructs a self-based on a foundation that does not change so much that all former identity is lost, all the 
while being aware that a self does change somewhat so that all experiences can be incorporated into a coherent self" (p.98).

Both philosophers agreed on the view that health is beyond the physiological aspect, with Descartes focusing on the efficiency of the mind and body while Ricouer pointed out that there should be complete balance of the person's physical, emotional, cognitive and spiritual self. Both views still sums up into one common understanding - that health is holistic, and each component identified by these two philosophers need to be integrated and should function to its highest capacity to achieve optimal well-being. The important relationship of health and the environment is presented in the next metaparadigm.

Environment. The metaparadigm of the environment focuses on the internal and external milieu that, directly or indirectly affects the person.

As Cartesian dualism presupposed that the mind and body are separate entities, the environment can then refer to external or internal context that affects the client. The body, as Sullivan (2001) argues, is affected by the external material context (Nath, 2013) such as temperature among other things. He further posited that the body, together with the external environment, contribute to the constitution of each other and are not capable of flourishing apart. While it is true that bodies and the external environment are coconstituted, they remain separate and cannot be collapsed into one thing. Being co-equal in importance with the body, the mind is also affected by its own "environment" (internal contexts). Though Descartes argues that the mind is immaterial, the functioning of the mind can be influenced by immaterial things as well. Words, emotions, beliefs and worldviews are by themselves immaterial things that do not affect the body but ultimately affects the workings of the mind. Hergenhahn (2009) claimed that because the mind is free it can modify whatever reflexive behavior as a result of exposure to the "environment". Much like in Cartesian dualism and Ricouer's selfhood, the environment can be viewed as a duality: an external material environment that is perceived by the senses as an extension of the body and an internal immaterial environment created and appreciated by the mind. This is parallel to Imogene King's appreciation of the environment as both being internal and external contexts (Masters, 2009)

Additionally, Ricouer, much like Benner (as cited by Masters, 2009), emphasized the social construct as part of environment by which human beings learn to understand themselves. Our body allows us to commune with the social realities that could be useful for understanding the 'environmental identity', as Drenthen (2015) posits. This way, environments provide us with a context with which to understand ourselves. This "social" environment is the collective context of human social experiences of everyday life that varies in space, time and quality. Societal dogmas, values, traditions, customs, and expectations are also part of this social milieu and needs to be constantly defined and understood through environmental hermeneutics. Specifically, this is a stance of philosophical hermeneutics. It starts with the recognition that the interpretations of the places in which we live provide an on-going and ever changing narrative context from which we can understand ourselves. This is the main concept of Ricoeur's philosophy - understanding human self.

The discussion presents the importance of the environment in the provision of care to the person.

The environment was shown to be internal and external, congruent to Descartes' philosophy on dualism of mind and body. Moreover, how the person adjusts to the environment around him also impacts his health recovery, consistent with Ricouers' view on a person's capacity to modify to his social environment to strengthen and cope with his vulnerability. The interplay in both the internal and the external environment plays a key role in the well-being and recovery of the person.

Having fully explained the relationship of the metaparadigm of person, health and environment to the discipline of nursing, the succeeding metaparadigm explores in detail how the philosophies of Descartes and Ricouer relate to the concept of nursing.

Nursing. Nursing is a profession grounded in the art and science of holistic health care. Considered as an emerging academic discipline, it is directed by the principles of human freedom, choice, and responsibility. In philosophy, nursing ontology examines the nature of nursing, personhood, environment and health (Bruce, Rietze, \& Lim, 2014). Further, Beerman, Snyder, and Frandsen (2016) define nursing as "the attributes, characteristics, and actions of the nurse (p. 64)" as nurses provide care with the client. Applying the philosophy of Cartesian dualism, nursing can be then seen as the attribute, characteristics and actions of a nurse as she cares for the client's mind and body. Though the Cartesian dualism emphasizes that the mind and body are of different entities, they need to exist in unison for the individual to live. Nursing then should never be only focused on caring for the mind or the body alone but ultimately, caring for the person 
who has a body and a mind.

Additionally, Ricouer's philosophical stance focused on understanding human and human experiences thru the context of communication. In his work "Asserting Personal Capacities and Pleading for Mutual Recognition" (2004), he asserts that a human has the capacity to speak, to act and to feel responsible (Garcia, 2011). He further believes that, human beings by nature understands and interprets meaning through the use of language, which possess varied meanings thus interpretation is essential (Dowling, 2011). Interpretation can occur if the nurse and the patient are both co-participants in the context of a nursing situation. This process of meaning making from Ricouer's philosophy when combined with the skeptical stance of Descartes enables nurses to completely understand the context of the patient and, in the process, allows them to create a narrative that facilitates not only self-awareness but knowing their patient as well. Furthermore, this narrative becomes a basis for nurses in making wise decisions regarding patient care; and at the same time opening expanded areas of opportunities for the patient. This is comparable to Hildegard Peplau's definition of nursing - an interpersonal process of therapeutic interaction between the nurse and the patient (Masters, 2009).

Through Ricouer's philosophy, nurses are given the possibility of re-evaluating the assumptions contained in their discipline by reconsidering the ethico-moral principles assumed in their unique role within the contemporary health care system. .

\section{INSIGHTS}

Person, as the object of nursing and health as its primary focus was exemplified in the philosophies of Descartes and Ricouer. The duality of the mind and body proposed by Descartes and the oneness of selfput forward by Ricouer both asserts the existence of mortal human beings capable of discovering meaning and making sense of their environment. The role of the nurse then should transcend from the mere act of healing the body of persons to caring for the totality their personhood.

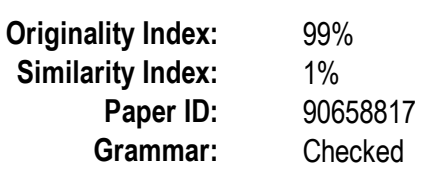

\section{REFERENCES}

Atkins, K. (2016). Paul Ricoeur, 1913-2005. In The Internet Encyclopedia of Philosophy. Retrieved from http://www.iep.utm.edu/ricoeur/
Beerman, A., Snyder, S., \& Frandsen, G. (2016). Kozier \& Erb's Fundamentals of nursing concepts, process, and practice $\left(10^{\text {th }}\right.$ ed.). New Jersey, USA: Pearson Prentice Hall..

Bennett, J. (1994). Descartes's theory of modality, The Philosophical Review, 103(4), 639-667.

Bruce, A., Rietze, L., Lim, A. (2014). Understanding philosophy in a nurse's world: What, Where and Why?. Nursing and Health, 2(3), 65-71.

Drenthen, M. (2015). Environmental hermeneutics and the meaning of nature. Oxford Handbook on Environmental Ethics. Retrieved from https://www.researchgate.net/publication/276418022_Environmenta 1_hermeneutics_and_the_meaning_of_nature

Dowling, W. (2011). Ricouer on time and narrative an introduction to temps et récit. Notre Dame, Indiana: University of Notre Dame Press.

Eckberg, D.L. \& Hill, L. (1979). The paradigm concept and sociology: A critical review. American Sociological Review, 44(6), 925-937.

Ernesto, E. Jr, Fabro, E. J., Faustino, F., Funcion, C., Guevarra, M., \& Mamengo, C. (2015). Key concepts of self-transcendence theory. Retrieved from http://n207pamelareedselftranscendence.blogspot.com/2015/09/key-concepts-of-selftranscendence.html

Flaming, D. (2005). Becoming a nurse: It's just who I am. Medical Humanities, 31(2), 95-100. doi: 10.1136/jmh.2005.000202

Fawcett, J. (1994). Analysis and evaluation of conceptual models of nursing. Philadelphia, PA: F. A. Davis.

Fawcett, J. (1984). The metaparadigm of nursing: present status and future refinements. Image: The Journal of Nursing Scholarship, 16(3), 84-87. doi:10.1111/j.1547-5069.1984.tb01393.x

Hutchins, R.M., (Ed) (1952). Great book of the western world. New York: Encyclopaedia Britanica.

Garcia, E. R. S. (2011). The capable human being according to Paul Ricoeur. A. B. Philosophy Thesis, University of Santo Tomas, 2011). Retrieved from https://www.scribd.com/doc/97599001/TheCapable-Human-Being-According-to-Paul-Ricoeur

Garrett, B. ( 2014). Science and modern thought in nursing: Pragmatism and praxis for evidence-based practice. United Kingdom: Northern Lights Media.

Hergenhahn, B. R. (2009). An introduction to the history of psychology. U.S. A.: Wadsworth Cengage Learning.

Hooft, S. V. (2006). Caring about health. England: Ashgate Publishing Limited.

International Council of Nurses (n.d.). Definition of Nursing. Retrieved from http://www.icn.ch/who-we-are/icn-definition-of-nursing/.

Kearney, R. (1988). Paul Ricoeur \& the hermeneutic imagination. Philosophy \& Social Criticism, 30(7), 115-145.

Locsin, R. C. (2017). The co-existence of technology and caring in the theory of technological competency as caring in nursing. The Journal of Medical Investigation, 64(1.2), 160-165.

Masters, K. (2009). Role development in professional nursing practice 4th ed. Massachusetts: Jones and Bartlett Learning, LLC.

Mason, T., \& Whitehead, E. (2003). Thinking nursing. United Kingdom: McGraw Hill Education.

Maville, J., \& Huerta, C. (2012). Health promotion in nursing. U.S.A.: Delmar Cengage Learning.

McBean, D., \& Wijck, F.V. (2013). Applied neuroscience for the allied health professions: An Introduction to Neuroscience. China: Churchill Livingstone Elsevier.

McCurry, M. K., Revell S. M. H, \& Roy. C. (2010). Knowledge for the good of the individual and society: Linking philosophy, disciplinary goals, theory, and practice. Nursing Philosophy, 11 (1), 42-52.

Murray, M. \& Chamberlain, K. (1999). Qualitative health psychology: Theories and methods. London: SAGE Publications.

Nath, S. ( 2013). Ryle as a critique of Descartes' Mind-Body Dualism. International Journal of Scientific and Research Publications, 3 (7), 1-5.

New World Encyclopedia. (2015). Philosophical anthropology. Retrieved from http://www.newworldencyclopedia.org/entry/Philosophical_anthrop ology

Orem, D. (1995). Nursing: concept of practice ( $5^{\text {th }}$ ed). St. Louis, MO: Mosby. 
Papineau, D. (2009). Philosophy. London: Duncan Baird Publishers Ltd.

Parvan, A. (2016). Monistic dualism and the body electric: An ontology of disease, patient and clinician for person-centered healthcare. Journal of Evaluationin Clinical Practice, 22(4), 530-538.

Pellauer, D. \& Daunenhauer, B. (2016). Paul Ricoeur, The Stanford Encyclopedia of Philosophy. Retrieved from https://plato.stanford.edu/entries/ricoeur/

Polkinghorne, D. E. (1988).Narrative knowing \& the human sciences. Albany: State University of New York Press.

Rummelsburg, S. (2015). Three perspective on the human person. The imaginative conservative. Retrieved from http://www.theimaginativeconservative.org/2015/05/three-

perspectives-on-the- human-person.html.
Skirry, J. (2005). Descartes and the metaphysics of human nature. London: Theommes.

Siringan, H. (2011). Philosophy of the human person. Quezon City. C \& E Publishing, Inc.

Sullivan, S. (2001). Living across and through skins: Transactional bodies, pragmatism and feminism. Bloomington, U.S.A: Indiana University Press.

White, K. (2006). The SAGE dictionary of health and society. London: SAGE Publication Ltd. 


\section{AUTHORS}

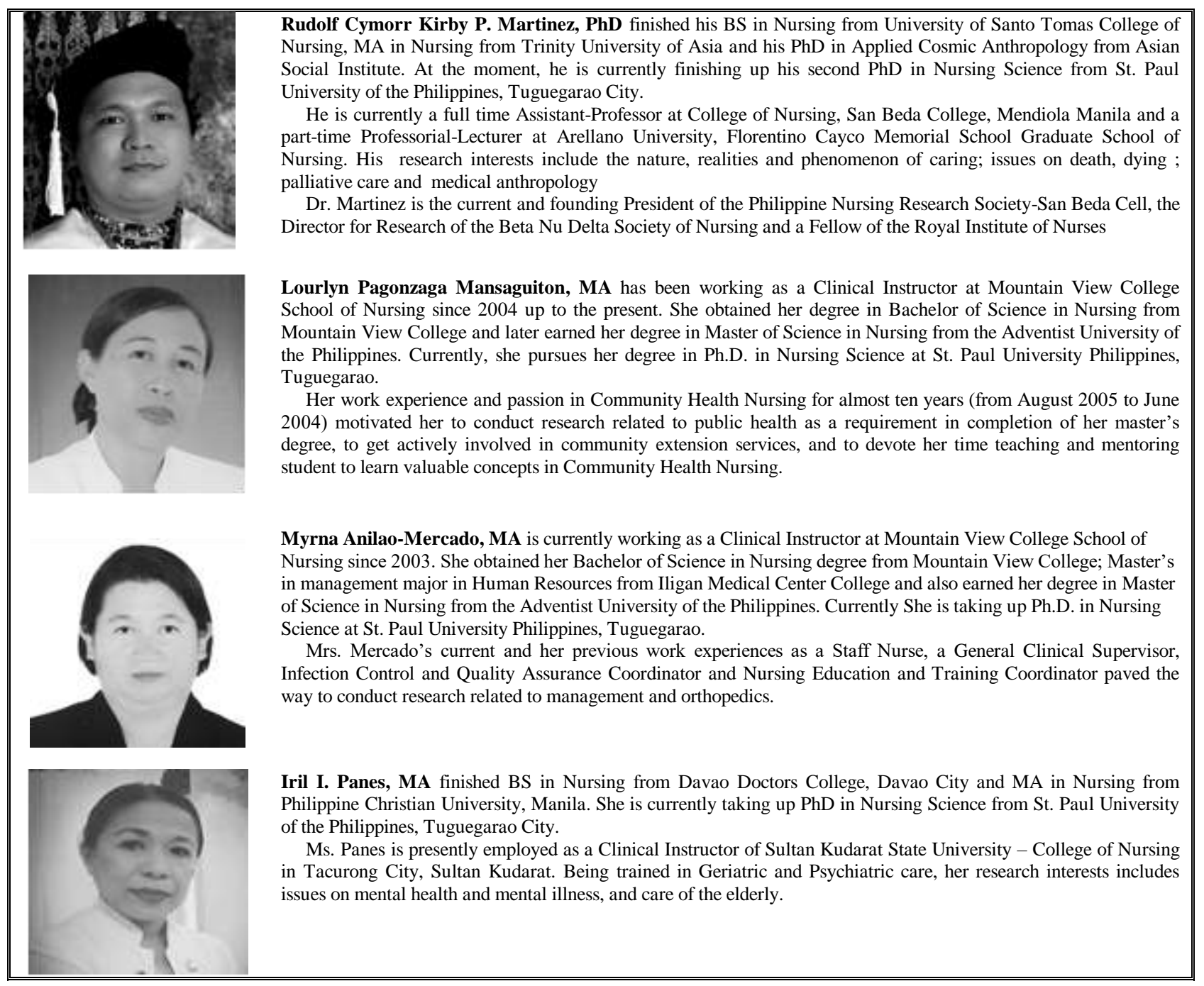

